This is a post-peer-review, pre-copyedit version of an article published in Journal of Public Health Policy. The final authenticated version is available online at: https://doi.org/10.1057/s41271-019-00165-6

Journal of Public Health Policy DOI:10.1057/s41271-019-00165-6

\title{
Multilevel Governance, Public Health and the Regulation of Food: Is Tobacco Control Policy a Model?
}

Donley Studlar ${ }^{1}$, Paul Cairney²*

1. Department of Health Services Management and Policy, College of Public Health, East Tennessee State University, Johnson City, TN 37614, USA

2. Division of History and Politics, University of Stirling, Stirling, UK ;

*Corresponding author: Email: p.a.cairney@stir.ac.uk

\begin{abstract}
Campaigns against risk factors for non-communicable diseases (NCDs) caused by smoking and obesity have become increasingly common on multiple levels of government, from the local to the international. Nongovernmental actors have cooperated with government bodies to make policies. By analyzing the policies of the World Trade Organization, World Health Organization, European Union, and United Kingdom and United States governments, we identify how the struggles between public health advocates and commercial interests reached the global level, and how the relatively successful fight to 'denormalize' tobacco consumption has become a model for anti-obesity advocates. It highlights three factors important in policy change: framing the policy problem, the policymaking environment, and 'windows of opportunity' - to analyse the struggle between 'harm regulation' and 'neoprohibition' approaches to an international obesity prevention regime.
\end{abstract}

\section{Introduction}

To improve global life expectancy, policymakers combine major efforts to prevent infectious diseases and the risk factors for non-communicable diseases (NCDs). The 2011 UN Highlevel Meeting on the Prevention and Control of NCDs refers to four risk factors - tobacco use, poor diet, lack of physical activity, and harmful use of alcohol - for the four major NCDs: cancer, cardiovascular diseases, diabetes, and chronic respiratory illnesses. In 2014, World Health Organization (WHO) warned of a 'cancer tidal wave' as the world population ages and engages in unhealthy behavior [1-2].

Nutrition has become a recognized policy problem globally over the past few decades, primarily with reference to obesity, but also excessive salt consumption. In the UK, the British Medical Association [3] connects poor diet to $41 \%$ of all deaths from cardiovascular disease, and Steel et al [4] attribute over $40 \%$ of 'years of life lost' to foodrelated causes, including poor diet and high blood pressure, cholesterol, and blood glucose levels. Questions about the relationship between nutrition and health, especially calorie- 
dense and nutrient-poor foods, have reached political agendas at various levels of government, ranging from New York City in the United States (US), to state/provincial governments, central government, international bodies such as the United Nations (UN), especially through the WHO and the Food and Agriculture Organization (FAO), the Organization for Economic Cooperation and Development (OECD), the World Bank (WB), and the European Union (EU). Since foods are consumer products, the issue is intertwined with international trade and the World Trade Organization (WTO) [5].Relatively new issues, nutrition policy for example, lack successful "exemplar programs" for prevention and/or regulation. [6-8] Advocates of policy change encourage learning from the more established pathway of tobacco policies in Western democracies, principally drawing lessons from the US, EU, individual members of the EU, and from the WHO Framework Convention on Tobacco Control (FCTC) [9-16]. From inauspicious beginnings, tobacco policy emerged over the past half century to be considered a public health success story, with major changes in policy and reductions in smoking leading to measurable benefits in quality and quantity of life [17].

If public health advocates would like to replicate this success and apply a similar model of policy change to issues such as nutrition and obesity, how can it be done? To identify the broad conditions that would have to be met to replicate tobacco control policy, we offer a tobacco/nutrition comparison based on a synthesis of insights from policy studies [18]. Our effort goes beyond analyses restricted to one level of government [9, 15, 19-22] towards a more abstract and 'universal' theory of policy change that applies across multiple levels of government. Evidence from tobacco suggests that three conditions must be present to support major policy change:

(1) supportive framing, in which policymakers describe the issue as an urgent public health problem

(2) a conducive policymaking environment, in which supportive departments or units (such as health departments or public health agencies) take primary responsibility, form networks primarily with public health actors (not industry representatives), and emphasise supportive socio-economic conditions (such as the net economic costs of unhealthy behaviour or growing public support for regulation)

(3) windows of opportunity, in which policymakers have a temporary motive and chance to adopt policy solutions that are technically feasible (will work as intended if delivered) and politically feasible (enjoy high and sustained support from key policy actors) [23-4]. 


\section{Lessons from tobacco: change the environment to change policy}

Tobacco control is the more established policy and has a trajectory over the past half century toward greater restrictiveness [25]. Successful tobacco policy change relates to the incremental adoption of many policy instruments to encourage smoking reduction and 'denormalisation' [26]. The cumulative weight of measures is impressive, moving from education, self-regulation, and limited advertising restrictions toward increasingly coercive instruments on price, promotion, health education, health warnings, plain packaging, and the regulation of ingredients, sales, who may smoke, and where they may smoke [17]. Until the rising importance of e-cigarettes, this has been a project based on 'neo-prohibitionism' (a term that perhaps highlights the strategy of some groups - but not the authors - to equate government regulation with Puritanism).

In contrast, harm regulation remains the dominant approach to food-related policy in bodies including the WHO and EU $[7,27]$. It may be possible to limit sales and consumption of some energy-dense foods, and regulate salt content in processed foods, in ways now common for tobacco products [28-30]. The norm, however, has been to meet minimum labelling standards on contents, presented in a way favoured by producers [31]. With a few global exceptions: unhealthy foods are taxed at the same rate as healthy foods; advertising restrictions are usually voluntary; there are few government-imposed warning labels; and, mandatory salt reduction measures are unusual [30].

Some action has begun on: warning labels, mandated advertising limits for children's television programming, differential taxation, and limits on sugary drinks [15, 21, 32-4]. But many efforts are countered successfully by opponents decrying excessive government intervention [28-9, 35]. Common, but inadequate, explanations of slow progress tend to describe a combination of low 'political will' to challenge vested interests and low attention to high quality scientific evidence [36].

Alternatively, we show that a major and sustained change of approach, driven by scientific evidence, would require a combination of three conditions [23].

- First, that actors use evidence to persuade policymakers to pay attention to, and shift their understanding of, policy problems. In tobacco, it took decades to command attention to the health effects of smoking, reframe tobacco as a global NCD epidemic, and generate support for effective evidence-informed solutions.

- Second, the policy environment is conducive to policy change. A new policy frame helps give public health units a greater role; they foster networks with health advocates at the expense of the industry; and, they emphasise the socioeconomic conditions supportive of policy change (reductions in unhealthy behaviour, opposition to regulation reductions, and the economic benefits of product use). 
- Third, actors successfully exploit 'windows of opportunity'. A supportive frame and policy environment maximizes the chances of high attention to an NCD epidemic and influences the motive and opportunity of policymakers to select relatively restrictive policy instruments. The political feasibility of such measures depends on factors such as timing and new knowledge-as 'second hand smoke' was a critical issue in stricter regulation of smoking [37-8]. It also depends on the ability of campaign groups to use key events (such as Big Tobacco's 'smoking gun' of the persistent denial of the health consequences of smoking) to exploit 'windows of opportunity' for policy changes [24]).

Scientific evidence is a necessary but insufficient condition for major policy change, even when the evidence seems unequivocal to scientists. Therefore, we identify key differences in tobacco/food policy change, then use the following questions to identify the conditions required to promote evidence-informed policy change:

\section{Agenda setting}

- Is there a clear public health frame, emphasising the NCD epidemic and a sense of urgency to solve it?

\section{The policymaking environment}

- Socioeconomic context: what is the prevalence of the problem? How important is this economic sector? Does the public support regulation?

- Policy networks: what is the balance of power between public health groups and the industry?

- Institutions: which organisation has the main responsibility for policy decisions, and how do its rules influence policy?

- Ideas: what is the role and status of scientific evidence? Does the government accept the public health evidence on harm? Does it draw on international action or policy lessons from other jurisdictions to address the problem?

\section{Windows of opportunity}

Can we identify key actors - across many levels of government - with the motive and opportunity to select new policy solutions?

\section{Nutrition/Obesity and Tobacco Control: Comparing Framing and Policy Environments}

Table 1 shows a summary of the current status of tobacco and obesity policymaking, viewed as a 'policy environment' in which choices are made. If our focus is multi-level, the comparison takes us beyond a simple focus on policy choices - such as international agreements - towards thinking about the likelihood of those choices being implemented in a meaningful way in policymaking environments conducive to their success. 
What would it take for nutrition policy to follow tobacco? The initial answer is that we would need to see the key changes in framing and environments that we have witnessed in tobacco, in many countries, in the post-war period.

\section{Table 1: Comparison of Global Tobacco and Nutrition Policy Environments}

\begin{tabular}{|c|c|c|c|c|c|}
\hline & Framing & Socioeconomic & Networks & Institutions & Ideas \\
\hline Tobacco & $\begin{array}{l}\text { Tobacco is } \\
\text { high on the } \\
\text { agenda and } \\
\text { framed as a } \\
\text { public } \\
\text { health } \\
\text { epidemic, } \\
\text { not an } \\
\text { economic } \\
\text { good }\end{array}$ & $\begin{array}{l}\text { Increasingly } \\
\text { favorable } \\
\text { economic } \\
\text { context; } \\
\text { increasing } \\
\text { public support } \\
\text { for controls }\end{array}$ & $\begin{array}{l}\text { Balance of } \\
\text { power has } \\
\text { shifted to } \\
\text { public } \\
\text { health } \\
\text { groups; } \\
\text { tobacco } \\
\text { companies } \\
\text { excluded }\end{array}$ & $\begin{array}{l}\text { Policy is } \\
\text { now led by } \\
\text { the WHO, } \\
\text { not } \\
\text { individual } \\
\text { states or } \\
\text { trade } \\
\text { divisions of } \\
\text { the UN }\end{array}$ & $\begin{array}{l}\text { The } \\
\text { scientific } \\
\text { evidence of } \\
\text { smoking and } \\
\text { passive } \\
\text { smoking } \\
\text { related harm } \\
\text { is accepted } \\
\text { within } \\
\text { government. }\end{array}$ \\
\hline Nutrition & $\begin{array}{l}\text { The nature } \\
\text { of the } \\
\text { problem is } \\
\text { disputed, } \\
\text { but there is } \\
\text { increasing } \\
\text { international } \\
\text { recognition. }\end{array}$ & $\begin{array}{l}\text { Increasing } \\
\text { public support } \\
\text { for regulation, } \\
\text { but behavior is } \\
\text { not always } \\
\text { consistent with } \\
\text { this. }\end{array}$ & $\begin{array}{l}\text { Balance of } \\
\text { power } \\
\text { remains } \\
\text { contested, } \\
\text { with food } \\
\text { producers } \\
\text { still } \\
\text { advantaged } \\
\text { but on } \\
\text { defensive. }\end{array}$ & $\begin{array}{l}\text { Policy } \\
\text { increasingly } \\
\text { led by WHO } \\
\text { and other } \\
\text { international } \\
\text { IGOs/NGOs }\end{array}$ & $\begin{array}{l}\text { Harm } \\
\text { reduction } \\
\text { remains the } \\
\text { norm, but } \\
\text { sugar and } \\
\text { salt } \\
\text { consumption } \\
\text { increasingly } \\
\text { identified as } \\
\text { key } \\
\text { problems. }\end{array}$ \\
\hline
\end{tabular}

Actors pursuing global tobacco control are now much more likely to have a favorable audience [17]. Institutionally, responsibility for tobacco control policy has shifted from individual countries to leadership by the WHO. Unlike multilateral trade organizations, the WHO has made tobacco control an overriding priority. Policymakers transformed the status of participants: the WHO and many governments excluded pro-tobacco groups from the policy process. The socioeconomic context has changed, with tobacco a less attractive economic benefit. Surveys now demonstrate majority public support in most countries for the FCTC. Tobacco control rose as a major public health problem on the global policy agenda. Policymakers have changed fundamentally the way they understand tobacco, from an economic product to be encouraged, to an evidently harmful practice to be discouraged and possibly eliminated. These changes have become mutually reinforcing, producing a policy environment conducive to public health policies [39].

There is less evidence of policy - and social - change in nutrition although there have been changes in the agenda. Obesity is a major concern in several levels of government, especially international, with a plethora of conferences and reports. Food producers remain 
major players [40], albeit in a defensive posture and altering some processes to forestall regulation. There is some government regulatory intervention. The excess consumption of sugar and salt is a major target, with some moves to label the former as addictive. However, the science of nutrition debate continues, focusing primarily on reducing rather than eliminating harmful behavior.

\section{Agenda setting: levels of attention and the policy's 'image'}

Tobacco was a glamorous product in the 1940s. It received minimal or positive media attention, and government encouragement as an economic good. Policymakers paid more attention to its contribution to ill health over the following several decades, and 'framed' it as a public health epidemic $[17,37,41]$. 'Cancer scare' stories became more prominent in the media of several countries, after the first widely publicised Anglo-American research findings on the hazards of cigarette smoking in the early 1950s, and the US Surgeon General's Report in 1964. Policy content changed more slowly, from the 1980s or 1990s in most Western democracies. Advocates of policy change used the growing evidence on the health effects of second-hand smoke (SHS), but the policies we might associate with SHS, such as indoor smoking bans, occurred decades after an initial rise of policymaker attention.

There are some signs of change in the WHO, but a definitive shift in nutrition policy is not present in any Western jurisdiction $[15,42]$. The tobacco experience gives some indication of the time lag - perhaps over decades - we might expect between a rise of attention to nutrition, attempts to 'reframe' food consumption primarily in relation to the prevention of NCD epidemics, and a proportionate policy response.

\section{Table 2: Chronology of International Activity and Reports on Nutrition/Obesity}

- 1977 US Dietary Goals (McGovern Report)

- 1979 EU Food Labelling Directive

- 1979 USDHEW Healthy People

- 1980 WHO-Europe Health for All in Europe (first of several)

- 1980 USDHHS and USDA Dietary Guidelines for Americans (first one, every five years thereafter)

- 1983 UK National Advisory Committee on Nutrition Education Guidelines

- 1983 UK Royal College of Physicians -country reports on obesity

- 1984 UK Committee on Medical Aspects (COMA) of Food and Nutrition Policy report

- 1988 US Surgeon General Report on Nutrition and Health

- 1988 WHO-Europe Healthy Nutrition: Preventing Nutrition-related Diseases in Europe

- 1990 WHO Expert Committee Report on Diet, Nutrition and the Prevention of Chronic Diseases

- 1990 First European Conference on Food and Nutrition Policies

- 1990 EU European Council Conclusions Action Program on Nutrition and Health

- 1990 EU Nutrition Labelling Directive

- 1992 WHO International Congress on Nutrition

- 1992 EU European Council Conclusions on Nutrition and Health, declaring 1994 European Nutrition Yr

- 1994 UK COMA report on diet and cardiovascular disease

- 1995 UK Department of Health, Nutrition Task Force, and Physical Activity Task Force report on obesity in England

- 1996 UK Department of Health and Nutrition Task Force report on nutrition and low incomes 
- 1998 WHO Task Force Report on Obesity

- 2000 EU Eurodiet guidelines

- 2000 EU, European Council Conclusions (Lisbon Agenda on Growth and Competitiveness)

- 2000 WHO Technical Report on Obesity

- 2000 WHO World Health Assembly Global Strategy for the Prevention and Control of Noncommunicable Diseases

- 2000 UK NHS Plan for England provides dietary guidelines

- 2001 US Surgeon General Report on Obesity

- 2002 EU Health in All Policies 2003-2008 (2002) (first decision providing EU legal basis for obesity prevention)

- 2002 WHO World Health Report

- 2002 International Obesity Task Force report, Obesity in Europe: A Case for Action

- $2003 \mathrm{EU}$, Council of the EU Conclusions on Health Lifestyles

- 2003 WHO/FAO Expert Committee Report

- 2003 WHO World Health Report

- 2003 UK House of Commons Committee report

- 2004 WHO World Health Assembly Global Strategy on Diet, Physical Activity, and Health

- 2004 EU, Council of the EU Conclusions on Heart Health

- 2005 EU, Forum on Nutrition, Health, and Physical Activity

- $2006 \mathrm{EU}$, Council of the EU Conclusions on Promotion of Healthy Lifestyles and the Prevention of Type II Diabetes

- 2007 EU, Obesity Prevention White Paper

- 2007 EU, High Level Group on Nutrition and Physical Activity (L and H, 153?)

- 2007 EU, Together for Health: A Strategic Approach for the EU 2008-2013

- 2007 UK Government Foresight Scientific Report, Tackling Obesities - Future Choices Project

- 2009 WHO 2008-2013 Action Plan for the Global Strategy for the Prevention and Control of Noncommunicable Diseases

- 2009 USFDA authority to require calories labelling in chain service food operations

- 2010 EU, Europe 2020: A European Strategy for Smart, Sustainable and Inclusive Growth

- 2010 OECD Report on Economic Costs of Obesity

- 2011 WHO Regional Office for Europe, Action Plan for Implementation of the European Strategy for the Prevention and Control of Non-communicable Diseases, 2012-2016

- $2011 \mathrm{EU}$, Council of the EU Conclusions on Closing Health Gaps with the EU through Concerted Action to Promote Healthy Lifestyle Behaviours'

- 2011 EU Food Information Regulation

- 2011 UN Political Declaration of the High-Level UN Meeting on the Prevention and Control of NonCommunicable Diseases

- 2011 WHO Global Status Report on Non-communicable Diseases

- 2011 UK DOH Policy Paper, Healthy Lives, Healthy People: A Call to Action on Obesity in England

- 2012 WHO Comprehensive Implementation Plan on Maternal, Infant and Young Child Nutrition

- UK Lancet Report on Disease Burdens

- 2013 WHO Global Action Plan for the Prevention and Control of NCDs 2013-2020

- 2014 EU, Third Health Programme 2014-2020

- 2014 WHO World Cancer Report

- 2014 WHO Global Status Report on Noncommunicable Diseases

- 2014 EU, Council of the EU, Conclusions on Nutrition and Physical Activity

- 2014 USFDA mandates posting of calorie counts in chain service food operations

- 2014 WHO World Health Assembly Meeting on NCDs

- 2014 UN High-Level UN Meeting on the Prevention and Control of Non-communicable Diseases

- $2014 \mathrm{FAO} / \mathrm{WHO} 2^{\text {nd }}$ International Conference on Nutrition (ICN2)

- 2014 McKinsey Global Institute Report on Obesity

- 2016 WHO Report of the Commission on Ending Childhood Obesity

- WHO Fiscal Policies for Diet and the Prevention of Noncommunicable Diseases 
- 2018 Strengthening Nutrition Action: A Resource Guide for Countries Based on the Policy Recommendations of the Second UN Conference on Nutrition (ICN2)

Sources: $[15,40,55,80]$

During the first conferences on nutrition in the early 1980s, there was little recognition that obesity would become a serious problem (Table 2). Then, the international 'food system' saw the growth of major transnational corporations producing overprocessed, nutrient-poor foods and beverages. This is what some non-governmental organizations (NGOs) describe as the agro-industrial production model that was responsible for nutrition-related problems, including the surge of obesity [43] and salt-intake related rises in 'blood pressure, cardiovascular disease and stomach cancer' [30: 1].

The language around this issue, among proponents of greater regulation, is changing in ways similar to the tobacco controversy. The WHO [44], that gave early and persistent warnings about smoking [17], describes a 'worldwide epidemic of cardiovascular diseases, cancer, diabetes and chronic respiratory diseases'. An 'obesogenic environment' fuels the obesity 'pandemic' and the manufacturers serve as 'disease vectors' [7, 15], prompting the WHO's World Cancer Report 2014 to urge preventive action such as regulations on sugar [2]. Protecting children from unhealthy consumption may become a routine rallying point. Yet, it is difficult to find in food a direct comparison to the no-safe-level of smoking frame (rather, there are WHO guidelines on per-person per-day consumption levels to seek, such as $5 \mathrm{~g}$ of salt). Scientific support for the general statement that poor diet is the largest contributor to NCDs has only reinforced patchy adoption of global measures, whose effect is relatively difficult to measure [30]. Some countries and the EU have taken some steps to address 'lifestyle' problems at an individual level, but there has not been a concerted effort at policy change to regulate population-wide behaviour [38].

\section{Socioeconomic Conditions}

In many countries, the falling economic benefits (including taxes, jobs, and exports), number of smokers, and opposition to control, provide a socioeconomic context more conducive to policy change [17, 45-6]. During the mid-twentieth century, in Western democracies, approximately half of the population smoked regularly. Smoking prevalence began a slow but persistent decline, first among more educated groups. While public opinion never clamoured for policy change, once changes began to be implemented, the population became increasingly supportive of restrictions on tobacco - a case of 'permissive consensus' despite initial fears of electoral repercussions [17].

Nutrition has yet to see this shift. In obesity, indicators suggest that people in general and children in particular have become increasingly overweight over several decades, leading to morbidity and mortality concerns similar to tobacco [42]. Six dietrelated risk factors account for 13.6 percent of global deaths, rising to 17.5 percent of 
deaths in the economically developed world [7]. The US leads the world, but other economically developed countries are gaining [47]. There has been a 'nutrition transition' over the past decades, from consumption of fresh fruits and vegetables toward fast energyproducing, low nutrition foods laden with sugar, salt, and fat [5: 17; 48]. Sugar has become a recent focus of attention as a possibly addictive substance [49]. The greatest risk of ill health from poor diet in developed economies is among lower-income groups. While the public demonstrates more concern, in most countries there has been no large shift to support changes in policy. There are patchy indications that the public may be willing to accept government-mandated measures to reduce sugar or salt, especially in foods aimed at children $[32,50]$.

\section{Networks}

The tobacco industry and its allies once dominated the attention of government, particularly in the US and UK in the early post-war period. That dominance allowed them to maintain a framing of tobacco based primarily on the immediate economic benefits. Anti-tobacco groups moved from the margins of the debate in the 1960s to the centre in the 1980s as they became more aggressive and cohesive (with scientists and advocates forming strong coalitions), using emerging scientific evidence to reframe the debate in relation to the health hazards of smoking, often in the face of tobacco lobby 'denialism' [51-3]. The image of tobacco companies shifted from patriotic providers of pleasure to the stigmatized 'Big Tobacco', a term used to describe a deceptive and dangerous manipulator of the public. In several countries, and particularly during negotiations of the FCTC, industry experts lost prestige and access to government officials [17].

While the food market is less oligopolistic than tobacco, there are a few large transnational corporations, sometimes organizationally linked to Big Tobacco. Health campaigners label it 'Big Food' [14: 7]. Large producers are supported by growers and others in the supply chain. Many growers benefit from government financial concessions that make their products cheaper, notably in the case of EU Common Agricultural Policy subsidies for sugar growing (until 2017) and the US government incentives for producing high fructose corn syrup [54].

Food producers have access to governments at high levels, giving them influence over policy decisions. Unlike tobacco, there is no 'smoking gun' to link the industry to misleading public statements and justify their exclusion. Further, governments rely on the industry to produce and supply food - a reliance phased out for tobacco as the agenda moved from supplying cigarettes to the US and UK troops in World War II towards the hope for smoke-free countries.

Western countries traditionally have consumer protection laws regulating food, especially what may be sold to children. More recent concerns about obesity have pitted 
health and children's advocacy groups against food producers. The food industry still resists regulation of products and marketing [14], to the point of litigation [21,55]. Commercial food producers and their networks generally support the status quo or make non-binding pledges to respond to threats of regulation. These include limitations on marketing to children under the age of 12. International groups of producers include the International Food and Beverage Association, and the EU Pledge group (a voluntary initiative by food and beverage companies to change the way they advertise to children, http://www.eupledge.eu) and various agricultural organizations. Despite attempts by the EU and Member State governments to involve the food industry in voluntary self- regulatory agreements on actions to improve nutrition, participation is sporadic $[15,55]$, contributing to the sense (long felt in tobacco control) that the measures serve more to smooth government-industry relations than change policy outcomes [56-7]. The UK government shifted from a strong to weakly enforced voluntary agreement after industry pressure [30: 3].

On the other side, a growing chorus of consumer affairs associations and nutritious food producers, and health and children's groups, ranging from the local to the international level, have attempted to shift policy through more stringent regulations. Such organizations include Consumers International, World Obesity Federation, the Non-Communicable Disease (NCD) Alliance, the World Public Health Nutrition Association, and C3: Collaborating for Health (a charitable organization registered in the UK, https://www.c3health.org). They promote international action through government alliances (the WHO Network on reducing marketing pressure on children) as well as networks of NGOs. A clear example of publicprivate international cooperation is the capacity-building effort of EPODE (Together, Let's Prevent Childhood Obesity) International Network. Founded in France, it consists of multiple levels of government and civil society organizations active in over 500 communities in six different countries [58].

At the World Health Assembly, WHO Director General Margaret Chan [59] announced the establishment of a Commission on Childhood Obesity. She voiced concern about the power of large corporations to challenge policies designed to protect and promote health, highlighted the role of processed foods as a driver of ill-health, and called for more funding for prevention activities. The WHO held a public consultation on the list of experts to be involved in this commission. Yet large food production groups did have a role.

\section{Institutions}

Tobacco and food often have different departments focusing on product promotion and control. Therefore, the primary department really matters. In tobacco, health departments took on increasing responsibility (from treasury and trade) over time, and their rules favoured the public health frame, consultation with public health groups, and epidemiological evidence. A similar process may have begun in obesity/nutrition without 
progressing far in many jurisdictions. Departments mainly concerned with food production still give ground only grudgingly to health considerations.

There is multilevel regulation of each issue and central governments have varying amounts of authority. Famously, coordinated judicial action by state governments in the US produced a more uniform tobacco regulatory policy through an out-of-court settlement with the major tobacco companies, but this was unusual [37]. Although EU regulatory capacity in public health is limited, it has influence over tobacco. As with the US states, the conditions to develop a harmonized, more restrictive policy on tobacco took years to develop and may be exceptional [17, 37]. Governments in countries like the UK go further than the EU agenda on control, while countries such as Germany have been far more reluctant, albeit adopting some form of control according to the EU and FCTC agendas [17].

US states policies on obesity remain uncoordinated. Food regulations are the preserve of local authorities, where some jurisdictions have taken action. Table 2 shows that the EU has become involved in obesity policy over the past 25 years, although it remains only a minor part of 'food policy' compared to the traditional concerns of availability and safety [55, 60-1]. The combination of regulation and self-regulation in EU nutrition policy through a mix of exhortation, best practices, and voluntary self- regulation is probably closer to the predominantly market-based approach to alcohol [55, 62]. Food is a complicated issue, with responsibility for policies distributed across several EU agencies. Current EU nutrition policies include providing subsidized milk, fruit, and vegetables for school lunches and for low-income families; consultations among Member State officials; encouraging voluntary self-regulatory initiatives by food producers; light regulations on marketing, and sponsorship, and evaluation of scientific research $[55,60]$. The EU has a repertoire of other policy tools but does not use them [15].

\section{International institutions}

At the international level, the main institutions are those within the $U N$, especially the WHO, but also the General Assembly, the FAO, and the World Bank (Table 1). The marketfriendly WTO serves as an adjudicator of what is allowable under international trade agreements and looms as a potential venue for NCD regulation by nations or other international bodies. Table 2 shows that increasingly the UN, especially through the WHO, has made recommendations on obesity as well as on tobacco. In 2014 there were three meetings: 1) a World Health Assembly (WHA) of the WHO; 2) a High-Level meeting on NCDs; and 3 ) the UN Second International Conference on Nutrition.

Depending on the commitments of its sovereign member states, the strength of the WHO regional affiliates varies considerably. The European WHO regional office is one of the more aggressive on NCDs [62]. The leadership of the WHO Secretary-General helped produce the FCTC - as the world's first public health treaty - and continuous 
implementation meetings [39]. This indicates that the WHO has considerable persuasive power, including incorporation of the EU as well as Member States as full adherents to the FCTC [63].

The WHO has increasingly addressed the problem of nutrition/obesity in overlapping initiatives. The nonbinding WHO Global Strategy on Diet, Physical Activity, and Health [64] proposed recommendations designed to reduce risk factors and improve access to healthy food. Some of the policy instruments in this document were first used in tobacco control, [5, 25]. The EU has made similar recommendations [33].

The first UN High Level Meeting on the Prevention and Control of NCDs in 2011 was only the second emergency meeting of the General Assembly to discuss a health crisis (the first was on HIV/AIDs in 2001). It brought together government officials and NGOs for a discussion of contributing factors to NCDs. A summary Political Declaration, agreed to unanimously by all 193 member-states, set out the challenges, called for a 'whole-ofgovernment and a whole-of-society effort', aimed to reduce risk factors and create healthpromoting environments, strengthen national polices and health systems, encourage international cooperation and collaborative partnerships with non-health actors, conduct research and development, engage in monitoring and evaluation, and called for follow-up reports [65].

The movement has not generated the sustained popular attention, individual country measures, and funding that the HIV/AIDS meeting did, perhaps because the problem is "impossibly large and complex" [66]. NCDs represent less than three percent of the official development aid (ODA) for health, and the problem has continued to worsen all over the globe. On the other hand, it has been firmly established as an ongoing concern for the UN, and countries have committed to a target of reducing premature deaths from NCDs by 25 percent by 2025 and to identify a process to produce consensus indicators on risk factors.

A later report summarized other developments toward regulation of food in the interest of noncommunicable disease in this period, thus [67] including moves to tax unhealthy and subsidize healthy foods, and reform trade regulations to ensure access to healthy foods. The second UN International Conference on Nutrition (ICN2) occurred in 2014, sponsored by the UN Food and Agriculture Organization (FAO) and the WHO, with the involvement of other UN agencies such as the World Food Program, UNICEF, and World Bank, plus a wide variety of countries, ministries, and NGOs. The participants issued two documents; 1) a broad commitment (Rome Declaration), and 2) a shopping list of policies and programs (Framework for Action). Once adopted by member states, these are meant to operate from 2016 until 2030 to rejuvenate the WHO global nutrition targets and noncommunicable disease targets [67]. ICN2 also recognized obesity as part of general development, nutrition, and food governance problems, including the formation of new 
alliances among health and development NGOs [68]. The UN subsequently issued a resource guide based on policies adopted at ICN2 and declared the UN Decade of Action on Nutrition 2016-2025.

While there are some trade restrictions on tobacco, the same is not true for obesityproducing foods. International trade treaties are influenced by commercial/trade and agricultural ministries, with health considerations normally a subsidiary concern. Even domestic marketing regulations on foods may be ignored in such agreements. The new conceptualization of public health, identifying noncommunicable diseases perpetrated by cross-border consumer products, posed an unforeseen dilemma for the WTO [5:4]. But the 2018 WTO decision in favor of plain packaging of cigarettes in Australia may encourage further regulation of dangerous consumer products.

\section{Ideas (1): Scientific information}

Scientific information is critical for policymaking on these issues. While public health practitioners may see the implications of findings about morbidity and mortality in consumption of these products as straightforward, some NCDs such as obesity, have longer lines of causality and conflicting findings, allowing for considerable dispute. Furthermore, industry-sponsored denial of scientific findings, often based on dubious research, selective evidence, and propaganda, has become a major factor in resistance to intrusive public health based policy changes [51]. The tobacco industry successfully employed such a strategy to deny regulation for many decades. The rise of more socialised concerns about the scientific effects of second hand smoking in the 1980s shook this resistance, and cigarettes became the focus of the problem [37].

Increasingly, sugar has become the target of obesity research. Actors describe "the New Tobacco" (a term now used in the popular press [69]), highlight the production of highcalorie fructose added to foods in Japan, the US, and Canada as a key problem [54], and argue that 'not all calories are the same', and that the consumption of sugar, especially by children in the form of candy and carbonated drinks, is a major driver of obesity $[49,70]$. The debate over sugar as a key factor in obesity has raged for some time, including to what level of sugar to limit and with what instruments, ranging from voluntary measures to incentives to taxation [67, 71-2]. Similarly, issues on how best to measure, evaluate, and address levels of salt consumption still feature in academic debate, albeit with some [73] arguing strongly that 'dissent' from scientific consensus comes from scientists funded by the industry.

In recent years, many countries have passed regulations on sugar - including Hungary, France, Mexico, Mauritius, Barbados, Chile, Belgium, Portugal, United Arab Emirates, Saudi Arabia, Thailand, Brunei, South Africa, and the United Kingdom [74] - and there are nascent salt reduction strategies in 75 countries [30]. Thus an evidence-informed 
consensus may be forming on specific sources of the NCD problem, providing a simplified diagram of cause-and-effect to make framing and adoption of policy easier. On the other hand, 'Big Food' is primed with its own researchers, publicists, and lawyers to resist reduction of its profits $[40]$. Studies $[7,14]$ document the similarities in preferences and resistance to stronger regulation in the food industry compared to the previous ones for tobacco. For instance, there have been complaints from corporate scientists about the 'demonization' of sugar on 'simplistic' grounds [32].

\section{Ideas (2) The New Public Health}

Underlying this dispute is a broader movement of ideas, usually labelled the New Public Health, health promotion, or Healthy Public Policy. This movement arose in the 1970s from concern that the barriers to increased life and health largely lay in individual and social behaviour (non-communicable diseases) rather than in infectious diseases and improved health care. In advocating public policies for improved general health and wellbeing, the New Public Health has generated controversy, even among public health scholars, over the relative benefits of collective choice over individual choice in lifestyle decisions [75-7]. Tobacco was the first major success of this movement as a broad 'epistemic' (knowledgebased) community organised to promote stronger regulatory policies [78]. While the epistemic community for nutrition/obesity is not yet as institutionalised and consensual, they have made progress on these fronts.

\section{Ideas (3) Diffusion}

One of the major factors leading to convergence of policies on tobacco and the FCTC was the diffusion of information and policy across international boundaries. The tobacco companies pioneered this, but anti-tobacco NGOs and countries followed [17, 34]. The first small World Tobacco or Health conference in 1967 grew to a broad international group of thousands attending recent conferences. There is now a periodic European Conference on Tobacco or Health and other organisations have proliferated on the internet [78].

Nutrition policy has not progressed as far. International diffusion on obesity information has accelerated over the past two decades, and the WHO and the EU have developed coordinating roles. While food consumption patterns vary, even in industrialised democracies, obesity is a recently increasing 'food harm' that is amenable to scientific analysis and similar polices. In principle, ameliorative measures could be transferred from one jurisdiction to another [15, 21, 54]. In fact, recently the WHO [44] produced a Global Status Report on Non-Communicable Diseases, listing nine goals, along with analyses of policy instruments used to attain these goals in different jurisdictions.

\section{Conclusion}


For several years, many groups have argued that serious public health problems, such as unhealthy food consumption, should be treated by government in a similar fashion to smoking. The reduction of the smoking rate in most industrial countries over the past half century is a major public health achievement. Through a multitude of international conferences sponsored by the UN, WHO, and EU, there is an effort to develop similar policies for obesity and other NCDs, and to integrate international policy on these issues. This includes an attempt to replicate the FCTC with a similar international treaty for noncommunicable diseases more broadly [79]. Considering the relatively short period of time that obesity has been defined as a problem on the political agenda, it has moved toward greater attention and the development of a wider array of potential policies in a sporadic and protracted manner towards stronger regulation [54]. The WHO has also assumed a more aggressive leadership role at an earlier point in the policy process.

Tobacco, however, remains an unusually advanced case in NCD prevention $[37,53]$ and will remain so until nutrition commands the same unequivocal framing (to describe the urgent need to reduce consumption of harmful products) and policy environment conducive to policy change. Without such shifts, it is difficult to envisage key advocates exploiting a series of 'windows of opportunity' for successful policy change. A window of opportunity opens when policymakers pay high attention to one way to frame a policy problem, a specific technically and politically feasible solution exists, and policymakers have the temporary motive and opportunity to select it [24]. Further, the tobacco experience shows that countries with supportive policy environments are more likely to produce a series of policy changes via such windows, while others agree to broad strategies without delivering specific measures in a meaningful way [23]. Therefore, perhaps over several decades, we are likely to see a growing focus on international strategies but with highly uneven implementation according to the ways in which each country's government defines the problem, takes it seriously, and promotes a policymaking environment conducive to continuous policy change.

\section{References}

1. Stewart, B. W., and C.P. Wild (eds). 2014. World Cancer Report 2014. Lyon: International Agency for Research on Cancer.

2. Gallagher, J. 2014. 'Cancer "tidal wave" on horizon, warns WHO'. BBC News: Health February 2. www.bbc.co.uk/new/health-26014693

3. British Medical Association (2018) Prevention before cure (London: BMA)

4. Steel, N. et al (2018) 'Changes in health in the countries of the UK and 150 English Local Authority areas 1990-2016: a systematic analysis for the Global Burden of Disease Study 2016', The Lancet, 392, 10158, 1647-1661 
5. McGrady, B. 2011. Trade and Public Health: The WTO, Tobacco Alcohol, and Diet. Cambridge: Cambridge University Press.

6. Swinburn, B.A., G. Sacks, K.D. Hall, K. McPherson, D.T. Finegold, M.L. Moodie and S.L. Gortmaker. 2011. The global obesity pandemic: shaped by global drivers and local environments The Lancet, 378 (9793): 804 - 814, 27 August 2011 doi:10.1016/S0140-6736(11)60813-1

7. Gilmore, A., E. Savell and J.Collin. 2011. 'Public Health, Corporations and the New Responsibility Deal; Promoting Partnerships with the Vectors of Disease?' Journal of Public Health 33 (1): 2-4; doi: 10.1093/pubmed/fdr008 First published online: February 2, 2011

8. Jacobsen, H. 2013 'Policy responses to obesity failing, EU experts admit'. EurActiv.com June 20. http://www.euractiv.com/health/eu-policy-responsesobesity-lack-news-528709 Accessed November 28, 2018.

9. Engelhard, C.L., A. Garson, Jr., and S. Dorn. 2009. Reducing Obesity: Policy Strategies from the Tobacco Wars. Washington: Urban Institute.www.urban.org

10. Klein, J.D. and W. Dietz 2010. 'Childhood Obesity: The New Tobacco'. Health Affairs 29 (3): 388- 392. http://content.healthaffairs.org/content/29/3/388.full

11. Kersh, R. and J. Morone. 2002. 'The Politics of Obesity: Seven Steps to Government Action'. Health Affairs 21 (6): 142-153.

12. Kersh, R. and J. Morone. 2005. 'Obesity, Courts, and the New Politics of Public Health.' Journal of Health Politics, Policy and Law 30 (5): 839-868

13. Weiss, R.I. and J.A. Smith. 2004. 'Legislative Approaches to the Obesity Epidemic'. Journal of Public Health Policy 25 (3): 379-390

14. Brownell, K.D. and K.E. Warner. 2009. 'The Perils of Ignoring History: Big Tobacco Played Dirty and Millions Died. How Similar Is Big Food?' Milbank Quarterly 87 (1): 259-294. Article first published online: 11 MAR 2009 DOI: 10.1111/j.14680009.2009.00555.x

15. Alemanno, A. and A. Garde. 2013. 'The Emergence of an EU Lifestyle Policy: The Case of Alcohol, Tobacco and Unhealthy Diets'. Common Market Law Review 50 (6): 17451786.

16. Lien, G. and K. Deland. 2011 'Translating the Framework Convention on Tobacco Control (FCTC): Can We Use Tobacco Control as Model for Other Non-communicable Disease Control?' Public Health 125 (12): 847-853. doi: 10.1016/j.puhe.2011.09.022. Epub 2011 Oct 29

17. Cairney, P., D. Studlar, and H. Mamudu. 2012. Global Tobacco Control: Power, Policy, Governance and Transfer. Basingstoke: Palgrave

18. Cairney, P. 2012. Understanding Public Policy. Basingstoke: Palgrave.

19. Enderlein, H., S. Wälti and M. Zürn. 2010. Handbook on Multi-level Governance. Cheltenham, UK: Edward Elgar. 
20. Studlar, D.T. 2014. 'Cancer Prevention through Stealth: Science, Policy Advocacy, and Multilevel Governance in the Establishment of a 'National Tobacco Control Regime' in the United States.' Journal of Health Politics, Policy and Law 39 (3): 505-535.

21. Gostin, L.O. 2013. 'Bloomberg's Health Legacy: Urban Innovator or Meddling Nanny?' Hastings Center Report 43 (5): 19-25. DOI: 10.1002/hast.208

22. Sisnowski, J., J.M. Street, and A. Braunack-Mayer. 2016. 'Targeting population nutrition through municipal health and food policy: Implications of New York City's experiences in regulatory obesity prevention'. Food Policy 58(1): 24-34.

23. Cairney, P. and Yamazaki, M. (2018) 'A comparison of tobacco policy in the UK and Japan: if the scientific evidence is identical, why is there a major difference in policy?' Journal of Comparative Policy Analysis 20 (3): 253-68

24. Kingdon, J., 1984, Agendas, Alternatives and Public Policies (New York: Harper Collins).

25. Studlar, D.T. and Cairney, P. 2014. 'Conceptualizing Punctuated and Non-Punctuated Policy Change: Tobacco Control in Comparative Perspective' International Review of Administrative Sciences 80 (3); Online First, published July 3, 2014 as doi:10.1177/0020852313517997

26. Cairney, P. (2019) 'The transformation of UK tobacco control' in (eds) Compton, M. and 't Hart, P. Great Policy Successes: How Governments Get It Right in a Big Way at Least Some of the Time (Oxford: Oxford University Press)

27. Bogart, W.A. 2013. Regulating Obesity? Government, Society and Questions of Health. New York: Oxford University Press.

28. Shaw, E. 2009. 'Le New Labour à la recherché de la meillure relation possible entre les individus l'Etat le marche'. Critique Internationale 43 (2): 51-68

29. Walters, S. and Owen, G. 2014.'Labour's nanny state plan for drinkers, smokers and "unhealthy" eaters sparks revolt in party'. Mail Online. 3 May. http://www.dailymail.co.uk/news/article-2619655/Labours-nanny-state-plan

30. Hyseni L, Elliot-Green A, Lloyd-Williams F, Kypridemos C, O'Flaherty M, McGill R, et al. (2017) 'Systematic review of dietary salt reduction policies: Evidence for an effectiveness hierarchy?' PLOS ONE https://doi.org/10.1371/journal.pone.0177535

31. Mwatsama M. (2016). Public health policy struggles: Comparison of salt reduction and nutrition labelling in the UK, 1980-2015. DrPH Thesis. London School of Hygiene and Tropical Medicine.

32. BBC News: Health. 2014. Poll shows most want sugary drinks banned from UK schools, May 4. http://www.bbc.com/news/health-27254780 Accessed November 29, 2018

33. Alemanno, A. and I. Carreño. 2011. 'Fat taxes in the EU between fiscal austerity and the fight against obesity'. European Journal of Risk Regulation (Issue 4/2011): 571576:

34. Hiilamo, H., E. Crosbie and S.A. Glantz. 2012. The evolution of health warning labels on cigarette packs: the role of precedents, and tobacco industry strategies to block 
diffusion. Tobacco Control, TC Online First, published on October 23, 2012 as 10.1136/tobaccocontrol-2012-050541

35. Holehouse, M. 2015. 'Cost of obesity, drug abuse and alcoholism to be revealed'. Daily Telegraph, 28 July.

http://www.telegraph.co.uk/news/health/news/11769531/Cost-of-obesity-drugabuse-and-alcoholism-to-be-revealed.html Accessed November 15, 2018

36. Cairney, P. 2016. The Politics of Evidence Based Policymaking:. London: Palgrave.

37. Studlar, D.T. 2002. Tobacco Control: Comparative Politics in the United States and Canada. Toronto: University of Toronto Press.

38. Studlar, D.T. 2015. 'Punching Above Their Weight through International Policy Learning: Tobacco Control Policies in Ireland'. Irish Political Studies 30 (1): 41-78.

39. Mamudu, H., P. Cairney and D.T. Studlar. 2015. 'Global Public Policy: does the new venue for transnational tobacco control challenge the old way of doing things?' Public Administration 93: 856-873. online: doi: 10.1111/padm.12143

40. Lang, T. and M. Heasman. 2004/ 2015. Food Wars: The Global Battle for Mouths, Minds and Markets ( $1^{\text {st }}$ and $2^{\text {nd }}$ eds). London: Earthscan.

41. Baumgartner, F. and Jones, B. (1993) Agendas and Instability in American Politics. Chicago: Chicago University Press

42. Dobbs, R., C. Sawers, F. Thompson, J. Manyika, J. Woetzel, P. Child, S. McKenna and A. Spatharouu. 2014. Overcoming Obesity: An Initial Economic Analysis. McKinsey Global Institute, November

43. Jonsson U and C. Schuftan. 2014. "International Conference on Nutrition. The real issues are being evaded." World Nutrition 5 (11): 925-928

44. WHO. 2014b. Global Status Report on Non-communicable Diseases. Geneva: World Health Organization.

http://apps.who.int/iris/bitstream/10665/148114/1/9789241564854 eng.pdf Accessed November 28, 2018.

45. Pacheco, J. 2011. 'Trends: Public Opinion on Smoking and Anti-Smoking Policies'. Public Opinion Quarterly 75 (3): 576-592

46. Bogart, W.A. 2011. Permit but Discourage: Regulating Excessive Consumption. New York: Oxford University Press.

47. OECD (2013) Health at a Glance 2013: OECD Indicators, OECD Publishing.

http://dx.doi.org/10.1787/health_glance-2013-en

48. Alemanno, A. and S. Gabbi (eds). 2014. Foundations of EU Food Law and Policy. Burlington, VT: Ashgate.

49. Lustig, R.H. 2013. Fat Chance: Beating the Odds against Sugar, Processed Food, Obesity, and Disease. New York: Hudson Street Press.

50. Oliver, J.E. and T. Lee. 2005. Public Opinion and the Politics of Obesity in America. Journal of Health Politics, Policy and Law 30 (5): 923-954. 
51. Oreskes, N. and E.M. Conway. 2010. Merchants of Doubt: How a Handful of Scientists Obscured the Truth on Issues from Tobacco Smoke to Global Warming. New York: Bloomsbury Press

52. McKee, M. and Diethelm, P. How the growth of denialism undermines public health BMJ. 2010 Dec 14;341:c6950. doi: 10.1136/bmj.c6950

53. Smith, K. 2013. Beyond Evidence-based Policy in Public Health. Basingstoke: Palgrave Macmillan.

54. Emanuel, E.J. and A.P. Steinmetz. 2014. 'Finally, Some Optimism about Obesity'. New York Times. May 4.

55. Garde, A. 2011. EU Law and Obesity Prevention. The Netherlands: Kluwer.

56. Baggott, R., 1986. 'By voluntary agreement: The politics of instrument selection'. Public Administration, 64(1), pp.51-67

57. Vogel, D. 1983. "Cooperative Regulation: Environmental Protection in Great Britain," Public Interest 72 (Summer): 88-106.

58. Borys, J.M. et al. (2012), 'EPODE approach for childhood obesity prevention: methods, progress and international development'. Obesity Review 13 (5): 299-315. Article first published online: 23 NOV 2011; DOI: 10.1111/j.1467-789X.2011.00950.x Accessed November 28, 2018.

59. Chan, M. 2014. Health has an obligatory place on any post-2015 agenda. Address to the Sixty-seventh World Health Assembly, Geneva, Switzerland 19 May 2014 http://www.who.int/dg/speeches/2014/wha-19052014/en Accessed November 28, 2018.

60. Friant-Perrot, M. and A. Garde. 2014. 'From BSE to Obesity: EFSA's Growing Role in the EU's Nutrition Policy' in Alemanno, A. and Gabbi, S. (eds) Foundations of EU Food Law and Policy. Burlington, VT: Ashgate, pp. 135-153.

61. Kurzer, P. 2012.'Non-communicable diseases; The EU declares war on 'fat,' in S.L. Greer and P Kurzer (eds.) European Union Public Health Policy: Regional and Global Trends. London: Routledge, pp. 155-167

62. Princen, S. 2009. Agenda-Setting in the European Union. Houndsmill, Basingstoke: Palgrave.

63. Mamudu, H. and D.T. Studlar. 2009. "Multilevel Governance and Shared Sovereignty: The European Union, Member States, and the FCTC." Governance 22: 73-97.

64. WHO. 2014a. Global Strategy on Diet, Physical Activity and Health. Geneva: World Health Organization. http://www.who.int/dietphysicalactivity/strategy/eb11344/strategy english web.p df Accessed November 28, 2018.

65. Cooper, K. 2011. The UN High-level Meeting on the Prevention and Control of NCDs (New York, 19-20 September 2011) and Associated Events. C3 Collaborating for Health. http://www.c3health.org/wp-content/uploads/2009/09/Complete-write-upof-UN-HLM-and-side-events-v-2-20111108.pdf Accessed November 28, 2018 
66. Johnson, T. 2012. 'Interview with Thomas Bollyky: UN High-Level Meeting on NCDs: One Year Later' Council on Foreign Relations. September 19 http://www.cfr.org/diseases-noncommunicable/un-high-level-meeting-ncds-oneyear-later/p29090 Accessed November 28, 2018.

67. WHO. 2016. Fiscal Policies for Diet and Prevention of Noncommunicable Diseases (NCDs). Geneva, May 5-6 2015.

http://www.who.int/dietphysicalactivity/publications/fiscal-policies-dietprevention/en/ Accessed November 14, 2018

68. FAO. 2014. ICN2: Second International Conference on Nutrition: Better Nutrittion, Better Lives. Rome. 19-21 November http://www.fao.org/about/meetings/icn2/en/ Accessed November 28, 2018.

69. Knapton, S. 2014. Sugar is as dangerous as alcohol and tobacco warn health experts.DailyTelegraph.January9. http://www.telegraph.co.uk/health/healthnews/10559671/Sugar-is-as-dangerousas-alcohol-and-tobacco-warn-health-experts.html Accessed November 28, 2018

70. Vartanian, L.R., M.B. Schwartz and K.D. Brownell. 2007. 'Effects of Soft Drink Consumption on Nutrition and Health: A Systematic Review and Meta-analysis'. American Journal of Public Health 97 (4): 667-675.

71. WHO. 2003. Diet, Nutrition and the Prevention of Chronic Diseases. Report of a Joint WHO/FAO Expert Consultation. WHO Technical Report Series 916. http://whqlibdoc.who.int/trs/who trs 916.pdf Accessed November 28, 2018.

72. Nestle, M. 2002. Food Politics: How the Food Industry Influences Nutrition and Health. Berkeley: University of California Press

73. Campbell, N. 2016. 'Dissidents and dietary sodium: concerns about the commentary by Donnell et al.', letter to the editor, International Journal of Epidemiology, 1-5 doi: 10.1093/ije/dyw292

74. Thornton, J. 2018. 'The UK Has Introduced a Sugar Tax, but Will It Work?' London School of Hygiene and Tropical Medicine' June www.ishtm.ac.uk Accessed November 15, 2018.

75. Larsen, L.T. 2012. 'The Leap of Faith from Disease Treatment to Lifestyle Prevention: The Genealogy of a Policy Idea'. Journal of Health Politics, Policy and Law 37 (2): 227252. https://doi.org/10.1215/03616878-1538611

76. Leichter, H. 1991. Free to Be Foolish: Politics and Health Promotion in the United States and Great Britain. Princeton: Princeton University Press.

77. Mayes, R. and T.R. Oliver. 2012. 'Chronic Disease and the Shifting Focus of Public Health: Is Prevention Still a Political Lightweight? Journal of Health Politics, Policy and Law 37 (2): 181-200. https://doi.org/10.1215/03616878-1538593

78. Mamudu H.M., M. Gonzalez and S.A. Glantz. 2011. 'The Nature, Scope and Development of the Global Tobacco Control Epistemic Community'. American Journal of Public Health 101(11): 2044-54. 
79. Consumers International and World Obesity Federation 2014. Recommendations towards a Global Convention to protect and promote healthy diets. May. http://www.worldobesity.org/site media/uploads/Convention on Healthy Diets FI NAL.pdf Accessed November 28, 2018

80. Baggott, R. (2010) Public Health: Policy and Politics (London: Palgrave)

About the authors:

Donley Studlar, (BA, MA, PhD) is Emeritus Professor of Political Science at West Virginia University and Adjunct Professor in the School of Public Health at East Tennessee State University.

Paul Cairney, (BA Hons, MSc, PhD), is Professor of Politics and Public Policy at the University of Stirling, UK (https://paulcairney.wordpress.com/ebpm/). 